\begin{tabular}{|l|l|l||}
\hline \multicolumn{2}{|c|}{ PublisherInfo } \\
\hline \hline PublisherName & $:$ & BioMed Central \\
\hline \hline PublisherLocation & $:$ & London \\
\hline \hline PublisherImprintName & $:$ & BioMed Central \\
\hline \hline
\end{tabular}

\title{
Noninvasive ventilation reduces nosocomial infections
}

\begin{tabular}{||l|l|l||}
\hline \multicolumn{2}{|c||}{ ArticleInfo } \\
\hline \hline ArticleID & $:$ & 4143 \\
\hline \hline ArticleDOI & $:$ & $10.1186 /$ ccf-1999-841 \\
\hline \hline ArticleCitationID & $:$ & 841 \\
\hline \hline ArticleSequenceNumber & $:$ & 80 \\
\hline \hline ArticleCategory & $:$ & Paper Report \\
\hline \hline ArticleFirstPage & $:$ & 1 \\
\hline \hline ArticleLastPage & $:$ & 3 \\
\hline \hline & $:$ & RegistrationDate : 1999-7-9 \\
ArticleHistory & $:$ & OnlineDate \\
\hline \hline ArticleCopyright & $:$ & Current Science Ltd1999-7-9 \\
\hline \hline ArticleGrants & $:$ & \\
\hline \hline ArticleContext & $:$ & 130541111 \\
\hline \hline
\end{tabular}




\section{Keywords}

Intensive care unit, noninvasive ventilation, nosocomial infection, prospective survey, ventilator associated pneumonia

\section{Comments}

This study is interesting and shows that NPPV is associated with less infection risk than ETI, however, the huge disparity between the groups and the fact that NPPV could only be used for a limited number of cases makes straight comparison between the groups impossible. Furthermore, only 24 and $44 \%$ of the NPPV group had central venous and urinary catheters respectively, this suggests this series of patients differ somewhat from UK ICU patients.

\section{Introduction}

When noninvasive positive pressure ventilation (NPPV) is used in the management of acute respiratory failure, complications are reduced and outcome improved when compared to endotracheal intubation (ETI). The noninvasive nature of NPPV could, therefore, be expected to lead to a decrease in nosocomial infection (NI) and improved outcome.

\section{Aims}

A prospective clinical and epidemiologic study to compare the methods of NPPV and ETI with the incidence of NI and ventilator acquired pneumonia (VAP).

\section{Methods}

Sequential patients requiring assisted ventilation, admitted to a French intensive care unit (ICU) over a 28 month period were enrolled in the study. NI rates were defined by standard guidelines. Indications 
for NPPV were chronic obstructive or restrictive pulmonary disease, acute pulmonary oedema or pneumonia. Other patients and those with any neurological compromise received tracheal intubation and NPPV. NPPV was provided with inspiratory pressure support to provide a $\mathrm{PaO}_{2}$ of $>8.5 \mathrm{KPa}$ and $\mathrm{SpO}_{2}$ of $>90 \%$. Pressure support of $12-16 \mathrm{cmH}_{2} 0$ with positive end expiratory pressure (PEEP) of up to 5 $\mathrm{cmH}_{2} \mathrm{O}$ was provided. ETI was used if any of the NPPV patients became dyspnoeic or neurologically obtunded. NIs were diagnosed on bacterial colony forming unit counts on catheters (PA, CVP lines, urinary), clinical diagnosis was used in the absence of a urinary catheter. VAP was diagnosed by standard criteria. Data collected included demographic data, simplified acute physiologic score (SAPS) II, length of ventilation and intubation. For patients in group NPPV-ETI NIs were deemed to be appearing in the ETI group if occurring 2 days after intubation and in the NPPV group if occurring within 2 days.

\section{Results}

A total of 129 patients were treated with NPPV and 25 of these subsequently needed ETI; 607 patients were intubated. There was a significant difference between the SAPS II score, age, diagnosis and length of hospitalisation between the groups. There were 245 episodes of NI (of note the mortality in those with NI was $24 \%$ and without $22 \%$ ), VAP was far more common after ETI. Of the patients ventilated noninvasively, NI was associated with significantly lengthened ICU stay.

\section{Discussion}

NPPV reduced the incidence of NI and VAP. Overall 138 of 154 patients with indications for NPPV were successfully treated and survived. Other cofactors for NI may have played a role - the risk is increased in trauma and in females.

\section{References}

1. Nourdine K, Combes P, Carton M-J, Beuret P, Cannamela A, Ducreux J-C: Does noninvasive ventilation reduce the ICU nosocomial infection risk? A prospective clinical survey. Intensive Care Med. 1999, 25: 567-573.

This PDF file was created after publication. 